\title{
Impact of Argument-Based Laboratory Method on Scientific Process Skills of Pre-Service Primary School Teachers and Their Views of The Nature of Science
}

\author{
Ceren Köseler ${ }^{1} \&$ Demet Şahin Kalyon ${ }^{2 *}$ \\ ${ }^{1}$ Bahçeşehir Collage, Tokat, Turkey \\ ${ }^{2}$ Department of Primary Education, Faculty of Education, Tokat Gaziosmanpasa University, Tokat, Turkey \\ *Correspondence: Demet Sahin Kalyon, Department of Primary Education, Faculty of Education, Tokat \\ Gaziosmanpasa University, Tokat, Turkey. E-mail: demet.sahin@gop.edu.tr
}

Received: September 11, 2020

Accepted: October 30, 2020 Online Published: November 12, 2020

doi:10.5430/jct.v9n4p75

URL: https://doi.org/10.5430/jct.v9n4p75

\begin{abstract}
The present study aimed to determine the impact of argument-based laboratory method on the scientific process skills of pre-service primary school teachers and their views on the nature of science.The study was designed based on the pretest-posttest quasi-experimental method and conducted with 64 sophomore pre-service primary school teachers (37 in the experimental group, 37 in the control group) studying a Primary Education Department. The dependent variables of the studies are the views of the pre-service primary school teachers on the nature of science and their scientific process skills, while the independent variable of the study was argument-based laboratory application The nature of science scale and scientific process skills tests were used as the data collection tools. The Argument Driven Inquiry approach was employed in the experimental group, while a conventional laboratory approach was implemented in the control group. The findings of the study revealed that the argument-based laboratory method have improved the student views on NOS and their scientific process skills.
\end{abstract}

Keywords: argument-based laboratory, nature of science, scientific process skills

\section{Introduction}

Curiosity is one of the most basic instinct that drives individuals. Throughout its existence, humankind had a sense of curiosity and exploration, and they have been living in pursuit of this instinct. The desire to recognize and understand the world and events, and to dominate nature lies under this emotion. The curiosity of humankind led to the birth of the concept of science. With the introduction of the concept of science, humankind has sought an answer to the question of what science is. Among scientists, there is still no consensus on what science is. The reasons why there is no consensus on a common definition are non-stationary nature of science, its indefinite scope, and limits for the subject-matter and research methods, and its versatile, and sometimes complex structure (Yildırım, 2010). Thus, instead of attempting to describe science with a single definition, a discussion on its nature would be a better approach.

The nature of science includes understanding what science is, its roles, who scientists are and their tasks, scientific clues, observations, events, rules, laws, and scientific methods, and how science is performed (Taşar, 2003). The concept represents what knowledge reflects, how a human being performs the act of knowing, the methods of constructing knowledge and beliefs, and values related to the production of science (Lederman, 2007). The purpose of science is to train individuals with critical thinking and lifelong learning skills who research and inquire. Students with these targeted skills are considered "science literate." Students must acquire and develop scientific process skills to understand the nature of science, learn how scientists work, and grasp scientific research methods.

Within the current educational approach, individuals are expected to question, research, and be active in the process of accessing information during learning independent of the discipline. Scientific process skills teach individuals to study like a scientist using scientific research methods. Within this context, teachers are considered the most important individuals who assist students in acquiring scientific process skills and developing a sense of 
understanding of the nature of science. Teachers enable students to improve their scientific skills and approaches through the methods and techniques they employ in the classroom. Argumentation is considered one of the most effective methods that can be used to improve this approach (Aslan, 2010; Gültepe, 2011; McDonald, 2010; Uluçınar-Sağır \& Kılıç, 2013)

\subsection{Nature of Science and Argumentation}

The reformations in national and international science education are based on assisting the students in understanding the nature of science because it is important for the acquisition of scientific literacy (Ministry of Education, [MEB], 2005, 2013, 2018, Association for the Advancement of Science [AAAS], 1993; National Research Council, [NRC], 1996). Although the concept of the nature of science was not included in science curriculum, the main objective of the curriculum is to emphasize the nature of science.

For the students to make personal and social decisions based on scientific knowledge, they should first understand how scientific knowledge is structured and consequently, the limits of scientific resources (Köseoğlu, Tümay, \& Budak, 2008). Understanding the nature of science can render this possible. The nature of science includes the characteristics of scientific knowledge and scientists, scientific publications, and how society and science affect each other (Doğan, Çakıroğlu, Bilican, \& Çavuş. 2009).

The nature of science includes the values and attitudes that exist in the nature and development of scientific knowledge (Lederman, 2007, p. 833). Because of the fact that the nature of science includes the methods of producing scientific knowledge, there is a close relationship between the argumentation employed in the production of scientific knowledge and the nature of science. Çetin, Erduran, and Kaya (2010) examined the relationship between the dimensions of argumentation and the nature of science among 114 pre-service chemistry teachers in different fields using the nature of science and argumentation tests. The findings revealed that there was a significant relation between the nature of scientific knowledge and argumentation. Some studies have reported that the engagement of the learners in argumentation can contribute to the development of their understanding of the nature of science, along with an increasing number of studies in the field of argumentation (Bell \& Linn, 2000; McDonald, 2010; Ogunniyi, 2006; Uluçınar-Sağır \& Kılıç, 2013; Yerrick 2010;).According to Driver, Leach, Millarr, and Scott (1996), understanding of the nature of science supports successful learning of scientific content and it is necessary for individuals to understand socio-scientific issues and participate in decision-making processes. This is the foundation of the correlation between NOS and argumentation. Previous findings revealed that argumentation has an effect on the of the students on nature of science. McDonald and McRobbie (2012: 983) examined the effect of student views on the nature of science on their argumentation skills, and the effect of argumentation on student perceptions on the nature of science and found a correlation between argumentation and the nature of science. Their findings revealed that the students' views on the nature of science affected their involvement in the argumentation process, and their argumentation skills and their capacity to come up with arguments increased in classes where argument-based activities were conducted to improve their understanding of nature of science. It was also determined that the views of the students, who were involved in the argumentation process, on the nature of science were affected, although no application distractors were used to change their views.

Studies examining the correlation between the nature of science and argumentation showed that the absence of a comparison group restricted the conclusions that were especially associated with the influence of argumentation on NOS in both studies (Khishfe, 2012). To eliminate this limitation, the study employed an experimental design with a control group.

\subsection{Scientific Process Skills and Argumentation}

Studies on education have started to attach importance to scientific process skills and basic life skills, focus on the use of approach and methods that predict the changes in today's condition (Alkış-Küçükaydın \& Uluçınar-Sağır, 2016). The objective of science course is to train science-literate individuals with the characteristics of scientists. They must acquire certain skills called scientific process in literature to train science-literate students. Scientific process skills are described as a comprehensive set of transferable skills that reflect scientific behavior (Padilla, 1990). The scientific process skills represent the rational and logical thinking skills required in science. Competence in scientific process skills enables students to act based on knowledge to produce solutions to problems (Burns, Okey \&Wise, 1985). All skills should be employed in a specific context, and scientific process skills are considered scientific only when they are applied in the context of science (Harlen, 1999). Scientific process skills are employed by scientists to study nature and producing knowledge (Özmen \& Yiğit, 2005) and are the basis of scientific inquiry (Harlen, 2000). Scientific process skills include the skills and contemplation processes that scientists need when they explore the environment (Çalışkan \& Kaptan, 2012). The active employment of the scientific process skills can lead 
to the transfer of these skills to different fields and topics because they can be generalized to all knowledge (Karahan, 2006). When students learn how to think, they experience intellectual development. Scientific process skills are an important aspect of intellectual development. Thus, acquiring scientific process skills should be a major goal in science instruction (Geban, Askar, \& Özkan, 1992). Teachers should select activities and instructional methods that emphasize scientific process skills. When students are given the opportunity to employ scientific process skills and encourage developing critical views on different content fields and contexts, these processes would support meaningful learning (Gültepe \& K1lı̧, 2015; Padilla, 1990). In a formal classroom setting, not only the understanding of children can be explored and extended, but also discussions and interpretations of their experiences advance between the teacher and children and among the children, then possibilities for practical investigations could emerge (Harlen, Macro, Reed, \& Schilling, 2003).

A primary teacher needs to learn science process skills. So that teacher can develop a scientific viewpoint related to the events in his environment. Besides, teachers need to experience these scientific stages directly to gain and improve science process skills (Guler \& Sahin, 2019). One of the practical research methods that could be used in the classroom is the argument-based activities.

This study aimed to determine the effect of argument-based laboratory method on the scientific process skills of pre-service teachers and their views on the nature of science. Based on this general purpose, the research question of the study was as follows: "What is the impact of argument-based laboratory method on the scientific process skills of pre-service teachers and their views on the nature of science?" ased on the aforementioned research question, the sub-problems of the study were as follows:

(1) Is there a significant difference between the pre- and post-application scientific process skills of the control group, pre-service teachers?

(2) Is there a significant difference between the pre- and post-application scientific process skills of the experimental group, pre-service teachers?

(3) Is there a significant difference between the pre- and post-application views of the control group, pre-service teachers, on the nature of science?

(4) Is there a significant difference between the pre- and post-application viewsof the experimental group, pre-service teachers, on the nature of science?

(5) Is there a significant difference between the post-application scientific process skills of the control group and experimental group pre-service teachers?

(6) Is there a significant difference between the post-application views of the control group and experimental group pre-service teachers on the nature of science?

\section{Method}

\subsection{Research Design}

The research design is a plan that the study consciously manages to answer the research questions or to test research hypotheses (Büyüköztürk, 2001). This study employed a pretest-posttest quasi-experimental design with the control group because they aim to identify causality between the variables (Büyüköztürk, 2001). The quasi-experimental design has the same objectives as the experimental design and the control and experimental groups in this research design are selected based on measurements, not random. A quasi-experimental design is used to estimate the causal impact of an intervention on your study population.

The dependent variables of this study were the views on the nature of science and the scientific process skills. In the research design, the independent variable, the effect of which on the experimental group was investigated, was the argument-based laboratory method. In the study, the equality of the group pretest scores was examined according to the study independent variables. Table 1 depicts the experimental model of the study. 
Table 1. The Quasi-Experimental Study Model

\begin{tabular}{|c|c|c|c|}
\hline & Pretest & Application & Posttest \\
\hline 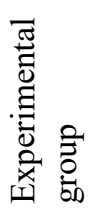 & $\begin{array}{l}\text { Nature of science scale } \\
\text { Scientific processkills test }\end{array}$ & $\begin{array}{l}\text { Argument based laboratory } \\
\text { applications }\end{array}$ & $\begin{array}{l}\text { Nature of science scale } \\
\text { Scientific process skills test }\end{array}$ \\
\hline 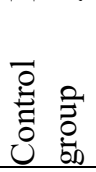 & $\begin{array}{l}\text { Nature of science scale } \\
\text { Scientific process skills test }\end{array}$ & $\begin{array}{l}\text { Laboratory applications with } \\
\text { closed-end experiments }\end{array}$ & $\begin{array}{l}\text { Nature of science scale } \\
\text { Scientific process skills test }\end{array}$ \\
\hline
\end{tabular}

\subsection{Sampling Procedures}

The study was conducted in the spring semester of the 2018-2019 academic year. The experimental group included 37 sophomore pre-service teachers attending the Faculty of Education, Primary Education Department, at a public university in the Central Black Sea Region. The control group included 37 sophomore pre-service teachers attending the Faculty of Education, Primary Education Department, at a public university in the Central Black Sea Region in Turkey. The purpose of this study was to reveal the impact of argument-based laboratory method on certain variables. In the assignment of the participants, the study employed the criterion sampling, one of the purposeful sampling methods. The acceptance criteria included attendance to the laboratory course for both groups and instruction with closed-ended experiments for the control group. In the selection of the participants, the criteria that experimental and control groups have previously taken a laboratory course in which closed-ended experiments were conducted and the control group continues closed-ended experiments in laboratory course during the application process has taken into consideration. The researchers found the laboratory applications conducted in a public university in the Eastern Black Sea Region suitable for the study objectives. It was determined that there was no significant difference between the pretest scores of the pre-service teachers in the experimental and control groups. Thus, it was assumed that the groups exhibited similar achievements in the baseline.

\subsection{Data Collection Tools}

\subsubsection{Nature of Science Scale}

The nature of science scale was developed by Sinan Özgelen (2013) to reveal the views of teachers and pre-service teachers on the nature of science.

Ozgelen (2013) reported that several nature of science scales have been developed since the 1950s; however, some important issues were identified regarding the validity of these scales. The study has a total of 655 participants with, 644 pre-service teachers attending four colleges and 11 science and technology teachers. Participation in this study was voluntary. The developed scale included 40 items in the draft form after the review of the national and international literature. Expert opinion was obtained from two professors who conducted studies in the field of science education and the nature of science. Based on the feedback provided by the experts, certain items in the draft scale were revised and hence some of them were excluded. After the revision, the total number of items was reduced to 35 . Based on the views of the pre-service teachers and in-classroom discussions, the number of items was reduced to 32 , and further to 30 based on the opinion of other experts. Out of the 30 scale items, 15 were reverse scored. Items $1,2,6,7,8,11,12,13,15,17,19,22,23,28,30$ are the reverse-scored items. Özgelen (2013) reported the Cronbach alpha score of the whole scale was .83. The scale includes 30 items in five dimensions with11 sub-dimensions.

Initially, factor analysis was conducted and Kaiser-Meyer-Olkin [KMO] and Bartlett's test of sphericity tests were applied, and it was determined that both KMO test results (.86) and Bartlett's test of sphericity result (.001) were significant. Cronbach's alpha internal consistency coefficient was .83. It was determined that the chi-square/degree of freedom $\left(\chi^{2 / \mathrm{df}}\right)$ ratio was .83 in IBM SPSS AMOS software applied to determine the confirmatory factor analysis with a 391 sample. It was concluded that the measurement model obtained with this ratio $(0.83)$ fitted well with the data (Özgelen, 2013).

Participants of this study were given 30 statements about the nature of scientific knowledge. Participants were asked to mark an "X" on their personal perceptions in spaces next to one of the following options: "I totally agree (TA)," "I mostly agree (MA)," "I partially agree (PA)," and "I do not agree (NA)." 


\subsubsection{Scientific Process Skills Test (SPST)}

The scientific process skills test was developed by Burns, Okey, and Wise (1985). The scale was adapted to Turkish by Geban, Aşkar, and Özkan (1992). The aim of the scale is to measure pre-service teachers' intellectual skills such as defining variables, defining, and understanding hypotheses, defining research, designing, and interpreting data, and plotting. The test includes 36 multiple-choice items, and each item has four options. Each question has only one correct answer. The participants receive 1 point for each question they answer correctly, 0 point for each question they answer incorrectly. The maximum and the minimum scores in the test are 36 and 0 , respectively. The participants were given 45 minutes to complete the test.

\subsection{Data Collection Process}

The study used the following two data collection tools as the pretest: the nature of science scale and scientific process skills test. The plan detailed below was implemented during a school semester.

The first week: The course was introduced to the pre-service teachers and the applications that would be conducted during the semester were explained. In the second week, the nature of science scale and scientific process skills test were applied as the pretest.

The second week: The activity to discover research-based science instruction models was conducted in this process. In this activity, students performed the assigned tasks in three different stations for a certain period. In the first station, a guideline with all necessary steps was provided and they were asked to reach the result. In the second station, the instructions for the event that they would conduct were partially provided and they were asked to reach the result. In the last station because it allowed open-ended questions, no further instruction was provided, and they were asked to try everything they could. After this activity, students recognized the different approaches in inquiry-based instruction and discussed the characteristics of these approaches.

The third week: In this process, the scientific process skills development activities were performed. In this activity, the students could exhibit their skills of observation and ask questions. Moreover, hypothesis, prediction, planning and research, interpretation and communication, and the features of these skills were discussed. For example, in the activity where the observation skill was exhibited, they were asked to draw their thoughts about what a candle would look like when it is lit, and they were told to label their drawings. Then they were asked to draw what they see when the candle is lit, then the differences between the two drawings and observation skills were discussed. The purpose of the activities is to acquire scientific process skills by performing an activity for each skill.

The fourth week: A researchable questioning activity was performed in the fourth week. In this activity, the students were provided with frozen water in a balloon one night before the activity and they were told that the substance was unidentified. They were asked to prepare researchable questions to identify the substance and research potential answers to these questions.

The fifth week. A query-based laboratory was performed in this week. In this activity, students were shown a box with a mechanism inside and asked to make inferences about the mechanism inside the box.

The sixth week. "Why does the moon appear in different forms? " question was asked in week six. Students were presented with two different views on lunar phases and asked to produce an argument as to why they adopted one of these views.

The seventh week: An unknown cell activity was conducted in this process. Students were first asked to examine plant and animal cell samples under a microscope and then given an unknown cell sample (plant or animal). Based on their previous observations, they were asked to produce an argument about what might be the unknown cell.

The eighth week: The osmosis and diffusion activities were conducted in this week. Pre-service teachers designed an experiment to test two different explanations about why erythrocytes appear larger when exposed to pure water, and tried answering the following question: "Why do red blood cells appear larger in pure water?" After the experiment, pre-service teachers came up with some arguments about answers to the question.

The ninth week: Chemical and physical changes activity was performed in this process. Students, in this activity, were expected to develop and observe five given scenarios. Based on their observations, they decided which one was a physical or a chemical change.

The tenth and 11th weeks: Physical properties of substances activity was conducted in weeks 10 and 11. A case was presented to the pre-service teachers for two weeks and they were asked to solve a murder case based on the information they obtained in the previous weeks. The twelfth week: The students were divided into groups and given a task of producing arguments and asked to produce their final written arguments. They were asked to answer the 
following question: "Is baking a potato a physical or a chemical change?" They were expected to produce arguments in response to the question.

The thirteenth week: In this week, the nature of science scale and scientific process skills tests were applied as posttest. When pre-service teachers were asked to produce arguments, they were asked to employ the Argument-Driven Inquiry (ADI) format. The applications were conducted for 11 and during six weeks, students produced arguments with the ADI approach. During the first five weeks, students participated in query-based laboratory practices. In addition, they were asked to produce arguments in these applications, but they were not asked to write reports. Conventional laboratory applications were conducted with the control group. The data collection tools employed as pretest were used as posttest at the end of the semester.

\subsubsection{Argument-Driven Inquiry}

The ADI instructional model is to frame the purpose of a laboratory activity as an effort to develop an argument that provides and supports an explanation for a research question. The ADI instructional model consists of the following seven steps: identification of the task, data generation, production of a tentative argument, argumentation session, creation of an investigation report, double-blind peer review, and revision of the investigation report (Walker, Sampson, Grooms, Anderson \& Zimmerman, 2012; Walker \& Sampson, 2013; Walker, Sampson, \& Zimmerman, 2011).

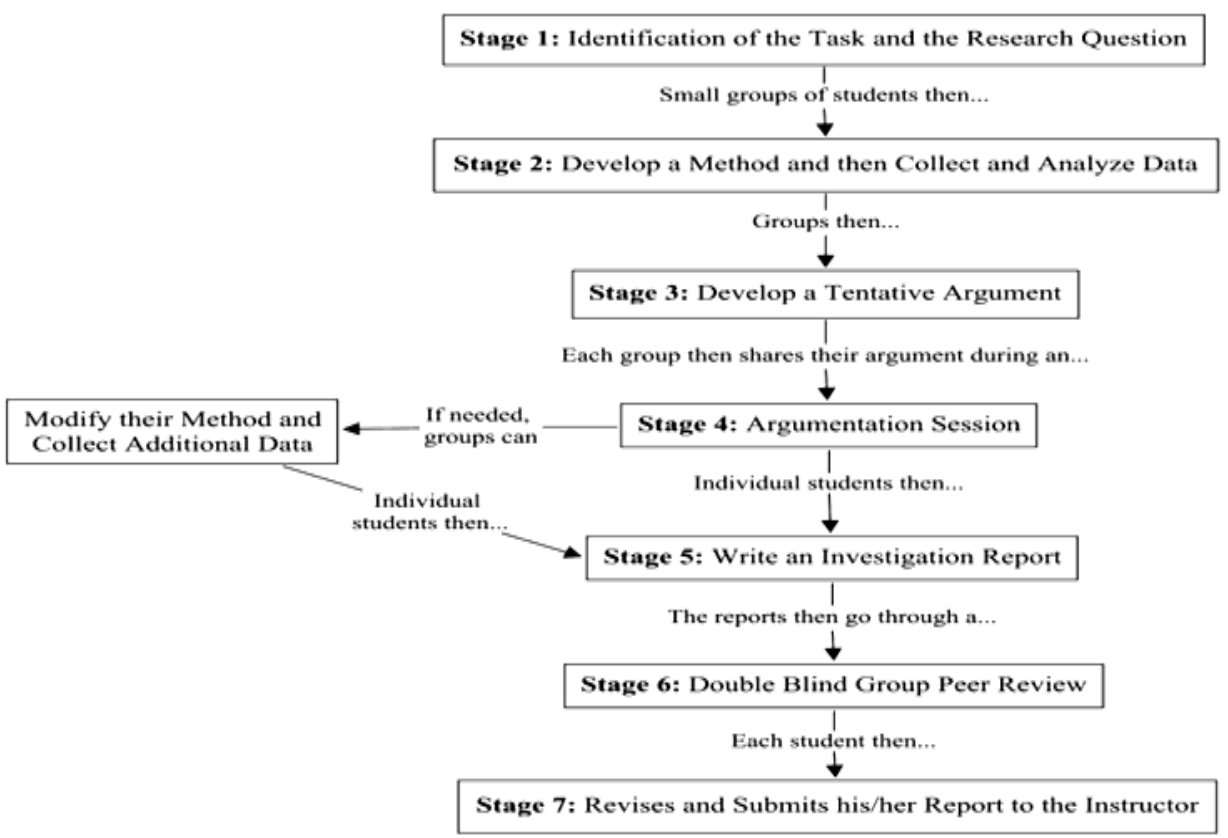

Figure 1. The Seven Steps of ADI

In this study, the last two stages were not conducted because of the laboratory course duration. The reports were reviewed, and feedback was provided by the authors. Prepared student reports were uploaded to the classroom application and the authors reviewed the reports about this application.

\subsubsection{Control Group Conventional Approach}

In the conventional approach, the teachers give step-by-step instructions and ask some procedural questions. Teachers often develop research questions and assign some tasks for students. Students follow a plan outlined by the instructor in the lab manual (Akkus, Gunel, \& Hand, 2007; Poock, 2005).

In this study, pre-service teachers in the control group conducted experiments based on the provided experiment plan. The experiment plan included the step-by-step tasks assigned to the pre-service teachers. In the control group, students worked in groups of five-six individuals the most. 


\subsection{Data Analysis}

Before conducting statistical procedures, the normal distribution of the data was investigated to determine which statistical method to employ.

\subsubsection{Normality Test of the Nature of Science Scale Data}

To conduct an accurate analysis, the normality tests of the nature of science scale and scientific process skills test pretest and posttest scores were determined. Initially, the experimental and control groups' scores were analyzed, then the experimental and control groups' pretest and posttest scores were analyzed. The findings are presented in Table 2.

Table 2 depicts that the nature of science scale and scientific process skills test pretest and posttest scores of the experimental and control group participants exhibited a normal distribution. Thus, the comparison of the pretest and posttest scores was conducted with the independent samples t-test for this scale. It was observed that scientific process skills test posttest scores of the experimental and control group participants did not exhibit a normal distribution. Thus, Mann Whitney U-test was employed in the comparison of the posttest scores in this scale.

Table 2. Descriptive Analysis of the Pre- and Post-Test Nature of Science Scale and Spst Data

\begin{tabular}{lllll}
\hline Test & Group & N & Kolmogorov-Smirnov & Shapiro-Wilk \\
\hline \multirow{2}{*}{ Nature of science scale Pretest } & Experimental & 37 & .077 & .514 \\
& Control & 37 & .200 & .496 \\
Nature of science scale Posttest & Experimental & 37 & .200 & .332 \\
SPST & Control & 37 & .200 & .311 \\
Pretest & Experimental & 37 & .125 & .376 \\
SPST & Control & 37 & .129 & .196 \\
Posttest & Experimental & 37 & .003 & .001 \\
\hline
\end{tabular}

Because of significant differences after the application, effect sizes were calculated to determine the degree of these differences (Cohen $\mathrm{d}$, eta square $\left(\eta^{2}\right)$ and $\mathrm{r}$ coefficient). The effect size is a standardized and objective measure of the observed effect sizes (Field, 2009, p.56). To determine whether the application was effective, Cohen's d and eta-squared values were calculated for the data with a normal distribution, and R-value was calculated for the data without a normal distribution. The R-value is calculated by the formula $\mathrm{Z} / \sqrt{ } \mathrm{N}$ and could be used in any case where the study group size is known (Rosenthal, 1991, p. 19). The $\mathrm{r}$ coefficient varies between 0 and 1 , and a value close to 1 indicates a high effect size (Field, 2009, p. 57). According to Cohen (1992), the effect size is considered small when $\mathrm{r}$ is .10 , moderate when it is .30 , and high when it is .50. The d-value, which can vary between $-\infty$ and $+\infty$ (Büyüköztürk, Çokluk, \& Köklü, 2018, p. 158), reflects a small effect size when it is .20, a moderate effect size when it is .50, and a large effect size when it is .80 (Cohen, 1988, p.25-26). The eta-squared value, which allows to determine the dependence of the variance in test scores on the independent or group variable, with.01score is considered small, .06 is considered moderate, and .14 is considered large effect size (Büyüköztürk, Çokluk, \& Köklü, 2018, p. 158)

Table 3. Descriptive Analysis of the Pre- and Post-Test Nature of Science Scale and Spst Data

\begin{tabular}{|c|c|c|c|c|c|}
\hline Scale & Group & Test & $\mathrm{N}$ & Kolmogorov-Smirnov & Shapiro-Wilk \\
\hline \multirow{4}{*}{$\begin{array}{l}\text { Nature of } \\
\text { scale }\end{array}$} & \multirow{2}{*}{ Experimental } & Pretest & 37 & .077 & .514 \\
\hline & & Posttest & 37 & .200 & .332 \\
\hline & \multirow{2}{*}{ Control } & Pretest & 37 & .200 & .496 \\
\hline & & Posttest & 37 & .200 & .311 \\
\hline \multirow[t]{4}{*}{ SPST } & \multirow{2}{*}{ Experimental } & Pretest & 37 & .125 & .376 \\
\hline & & Posttest & 37 & .003 & .001 \\
\hline & \multirow{2}{*}{ Control } & Pretest & 37 & .129 & .196 \\
\hline & & Posttest & 37 & .025 & .076 \\
\hline
\end{tabular}


As Table 3 depicts the nature of science scale pretest and posttest scores of the participants in the experimental and control groups exhibited a normal distribution. Thus, the comparison of the nature of science scale pretest-posttest scores in the experimental group was conducted with the dependent samples t-test. However, it is possible to suggest that the scientific process skills test pretest scores of the participants in the experimental and control groups exhibited a normal distribution and the posttest scores did not exhibit a normal distribution. Thus, the Wilcoxon Signed Ranks test was used in the comparison of the scientific process skills test pretest-posttest scores of the experimental and control groups.

\section{Results}

\subsection{First Sub-Problem Findings}

The Wilcoxon Signed Ranks test was used to determine whether there was a difference between the scientific process skill test pretest and posttest scores of the pre-service teachers in the control group. Table 4 presents the findings of the Wilcoxon Signed Ranks test.

Table 4. The Comparison of Scientific Process Skills Test Pretest and Posttest Scores of the Control Group

\begin{tabular}{llllll}
\hline Posttest -Pretest & $\mathrm{N}$ & Mean Rank & Total Rank & $\mathrm{z}$ & $\mathrm{p}$ \\
\hline Negative Rank & 5 & 6.70 & 33.50 & 3.98 & .00 \\
Positive Rank & 24 & 16.73 & 401.50 & & \\
Equal & 30 & & & \\
\hline
\end{tabular}

As Table 4 depicts, there was a significant difference between the scientific process skills test pre- and post-test scores of pre-service teachers in the control group $(\mathrm{z}=3.98, p<.05)$. Based on the mean and total ranks of the score differences, the difference was in favor of positive rank, that is, the posttest score. Based on these findings, it is safe to say that the laboratory course had an impact on the scientific process skills of pre-service teachers in the control group. The effect size was calculated to determine the size of this difference that favored the posttest scores in the control group. The findings depicted that the calculated effect size $(r=.72>.50$ high effect) was high for the difference between the pretest-posttest mean scores.

\subsection{Second Sub-Problem Findings}

The Wilcoxon Signed Ranks test was conducted to determine whether there was a difference between scientific process skill test pretest and posttest scores of the pre-service teachers in the experimental group. Table 18 shows the findings of the Wilcoxon Signed Ranks test.

Table 5. The Comparison of Scientific Process Skills Test Pretest and Posttest Scores of the Experimental Group

\begin{tabular}{llllll}
\hline Posttest -Pretest & $\mathrm{N}$ & Mean Rank & Total Rank & $\mathrm{z}$ & $\mathrm{p}$ \\
\hline Negative Rank & 4 & 6.63 & 26.50 & 4.24 & .00 \\
Positive Rank & 26 & 16.87 & 438.50 & & \\
Equal & 0 & & & & \\
\hline
\end{tabular}

As Table 5 shows, there was a significant difference between the scientific process skill test pre- and post-test scores of the pre-service teachers in the experimental group $(\mathrm{z}=3.98, \mathrm{p}<.05)$. Based on the mean and total ranks of the score differences, the difference was in favor of positive rank, that is, the posttest score. The findings revealed that argument-based laboratory method conducted with the experimental group had a significant impact on the scientific process skills of the pre-service teachers. The effect size was calculated to determine the size of the difference that favored the posttest scores in the experimental group. The findings of the analysis revealed that the effect size $(\mathrm{r}$ $=.77>.50$ high effect) was high for the difference between the mean pretest and posttest scores.

\subsection{Third Sub-Problem Findings}

The t-test was conducted to determine whether there was a difference between the nature of science scale pretest and posttest scores of the pre-service teachers in the control group. Table 6 shows the findings of the t-test. 
Table 6. The Comparison of Control Group Nature of Science Scale Pretest and Posttest Scores

\begin{tabular}{lllllll}
\hline Measurement & $\mathrm{N}$ & $\overline{\mathrm{X}}$ & $\mathrm{S}$ & $\mathrm{sd}$ & $\mathrm{t}$ & $\mathrm{p}$ \\
\hline Pretest & 31 & 2.53 & .28 & 30 & 3.52 & .00 \\
Posttest & 31 & 2.74 & .22 & & & \\
\hline
\end{tabular}

It was determined that the conventional laboratory applications conducted with the control group led to a difference in the nature of science scale scores of the students $[\mathrm{t}(30)=3.52, \mathrm{p}<.05]$. As Table 6 shows, the mean pretest scale score of the students was $\bar{X}=2.53$, while the mean posttest scale score was $\bar{X}=2.74$. This finding depicted that laboratory applications where close-ended experiments were conducted had an impact on student perceptions on the nature of science. The effect size was calculated to determine the magnitude of the difference observed in favor of the nature of science scale posttest scores of the pre-service teachers in the control group. The two calculated effect sizes $\left(\mathrm{d}=.63>.50\right.$ moderate effect; $\eta^{2}=.29>.14$ high effect $)$ demonstrated a moderate-high effect size for the difference between the mean scores. The findings of the Eta square test revealed that $29 \%$ of the variance in the posttest scores of the pre-service teachers in the control group was explained by conventional laboratory applications.

\subsection{Fourth Sub-Problem Findings}

The t-test was conducted to determine the difference between the nature of science scale pretest and posttest scores of the pre-service teachers in the experimental group. Table 7 presents the findings of the t-test.

Table 7. The Comparison of Experimental Group Nature of Science Scale Pretest and Posttest Scores

\begin{tabular}{lllllll}
\hline Measurement & $\mathrm{N}$ & $\overline{\mathrm{X}}$ & $\mathrm{S}$ & $\mathrm{sd}$ & $\mathrm{t}$ & $\mathrm{p}$ \\
\hline Pretest & 37 & 2.66 & .31 & 36 & 4.62 & .00 \\
Posttest & 37 & 2.92 & .32 & & & \\
\hline
\end{tabular}

It was determined that the argument-based laboratory approach led to a difference in the nature of scientific knowledge scale scores of the students in the experimental group $(\mathrm{t}[36]=4.62, \mathrm{p}<.05)$. The findings showed that the mean pretest scale score of the students was $\bar{X}=2.66$, and the mean posttest scale score was $\bar{X}=2.92$. These findings depicted that argument-based laboratory method had an impact on students' perceptions on the nature of scientific knowledge. The effect size was calculated to determine the magnitude of the difference that favored the nature of science scale posttest scores of the pre-service teachers in the experimental group. The two calculated effect sizes $\left(\mathrm{d}=.75>.50\right.$ moderate effect; $\eta^{2}=.37>.14$ high effect) indicated that there was a moderate-high effect size of the difference between the mean scores. According to the eta-squared test results, which exhibited a high effect size, $37 \%$ of the variance in the posttest scores of the pre-service teachers in the experimental group was explained by the application.

\subsection{Fifth Sub-Problem Findings}

Mann-Whitney U-test was conducted to determine whether there was a difference between the scientific process skills test posttest scores of the experimental and control groups. Table 8 shows the findings of Mann-Whitney U-test.

Table 8. The Comparison of Experimental and Control Group Scientific Process Skills Test Posttest Scores

\begin{tabular}{llllll}
\hline Group & $\mathrm{N}$ & Mean rank & Total rank & $\mathrm{U}$ & $\mathrm{p}$ \\
\hline Experimental & 30 & 38.55 & 1156.50 & 208.5 & .00 \\
Control & 30 & 22.45 & 673.50 & & \\
\hline
\end{tabular}

As shown in Table 8, it was determined that there was a significant difference between the scientific process skill test scores of pre-service teachers in the experimental group where the argument-based laboratory method were conducted and the scores of the pre-service teachers in the control group (U: 208.5, $\mathrm{p}<.05$ ). The mean ranks revealed that the scientific process skills of the pre-service teachers in the experimental group were higher compared to the control group. This finding may indicate that argument-based laboratory method were effective on the improvement of the scientific process skills. The effect size was calculated to determine the magnitude of the significant difference 
in the posttest scores that favored the experimental group. The findings demonstrated that the effect size $(r=.46>.30$ moderate effect) was moderate for the difference between the mean posttest scores of the experimental and control groups.

\subsection{Sixth Sub-Problem Findings}

The t-test was conducted to determine whether there was a difference between the nature of science scale posttest scores of the experimental and control groups. The findings are presented in Table 9.

Table 9. The Comparison of Experimental and Control Group Nature of Science Scale Posttest Scores

\begin{tabular}{lllllll}
\hline Group & $\mathrm{N}$ & $\overline{\mathrm{X}}$ & $\mathrm{S}$ & $\mathrm{sd}$ & $\mathrm{t}$ & $\mathrm{p}$ \\
\hline Experimental & 37 & 2.91 & .32 & 66 & 2.58 & .01 \\
Control & 31 & 2.74 & .22 & & & \\
\hline
\end{tabular}

The findings showed that argument-based laboratory application influenced student perceptions on the nature of science $(\mathrm{t}[66]=2.58, \mathrm{p}<.05)$. The experimental group scale scores $(\overline{\mathrm{X}}: 2.91)$ were higher when compared to the control group scale scores $(\overline{\mathrm{X}}: 2.74)$. These findings suggested that the argument-based laboratory method positively affected the student perceptions on the nature of scientific knowledge. The effect size was calculated to determine the magnitude of the difference between the nature of science post-test scores of the pre-service teachers in the experimental and control groups that favored the experimental group. The two calculated effect sizes $(\mathrm{d}=.62>.50$ moderate effect; $\eta^{2}=.09>.06$ moderate effect) demonstrated the effect size was moderate for the difference between the mean scores. The analysis of the eta-squared test revealed that $9 \%$ of the variance between the group posttest scores is explained by the argument-based applications.

\section{Discussion}

The argumentation is considered a type of discussion where logical inferences are made based on evidence (Driver, Newton, Osborne, 2000; Kelly, Chen, \& Crawford, 1998; Kuhn, 2005; Lemke, 1990). In other words, it entails logical inferences by the association of the claim and the data and assessment of the claims based on experimental and theoretical evidence (Jimenez-Aleixandre \& Erduran, 2007). Argumentation is a form of discussion that employs evidence to obtain a logical inference and could be observed in daily discussions of the scientists. The nature of science includes the definition of science, scientists, and scientific tasks, methods, and how to conduct science (Taşar, 2003). Scientific process skills were defined as a comprehensive set of transferable skills that reflect scientific behavior (Padilla, 1990). These include the skills frequently employed by scientists in their studies such as observation, measurement, classification, data recording, hypothesizing, data modeling, changing and checking variables, and experimenting (MEB, 2013). Studies revealed that argumentation, the nature of science and scientific process skills are interrelated, and studies demonstrate that this correlation is required. That is why the purpose of this study was to determine the impact of argument-based laboratory method on the scientific process skills of the pre-service teachers and their views on the nature of science.

The study findings depicted that there was a significant difference between the pretest and posttest scores of the control group where close-ended experiments were performed and the experimental group where argument-based applications were performed. The effect sizes results showed that both applications were effective at large. One of the places where students can acquire scientific process skills is laboratories. Şimşekli and Çalış (2008) examined the impact of laboratory applications on the scientific process skills of classroom teachers. They observed that the theoretical instructions and applications conducted during the course led to a significant improvement in the related skills of the students. Other studies determined that science laboratory applications had an effect on the development of scientific process skills of pre-service teachers (Aydoğdu \& Buldur, 2013; Şahin-Pekmez, Aktamış, \& Can, 2010). Gültepe and Kılı̨̧ (2015) reported that both traditional instruction and argument-based instruction approaches contributed to the development of the integrated scientific process skills of the students. Traditional experiments do not lead to adequate cognitive development among students. When traditional experiments are performed, the development of student skills is limited. Furthermore, studies revealed that traditional laboratory applications do not provide adequate opportunities for the students to generate arguments and assess their peers' arguments and the development in their scientific process skills, their understanding about the nature of scientific knowledge, their critical thinking, research and judgment skills would be poor (Şekerci \& Canpolat, 2014). 
Pre-service teachers experience processes such as observation, measurement, and data collection in traditional laboratory applications; however, they do not have the opportunity to experience processes such as problem identification, research problem development, method determination, research design and implementation, data collection and interpretation, and drawing conclusions (Ulu \& Bayram, 2014).

After the applications with the experimental and control groups, an increase in scientific process skills was detected. The findings of the study revealed that the difference between the two groups based on skills favored the experimental group. The findings depicted that the impact of the argument-based laboratory method on the development of scientific process skills was partially high. The related effect size was moderate. The reason for the moderate effect size was the impact of traditional laboratory applications on students' scientific process skills. This finding was consistent with previous studies' findings postulating argument-based laboratory method improved scientific process skills (; Demircioğlu \& Uçar, 2015; Gültepe \& K1lıç, 2015; Şekerci \& Canpolat, 2014).

According to the study findings, it appears that argument-based laboratory method had an impact on students' views on the nature of science. The related effect size was moderate. The reason for the moderate effect size was the impact of traditional laboratory applications on students' views on the nature of science. Studies reported that argument-based applications have an impact on students' perceptions on the nature of science conducted with middle school, high school and college students (Acar, Tola, Karacam \& Bilgin, 2016; Bell \& Linn, 2000; Cook \& Buck, 2013; Gümrah, 2013; Kutluca \& Aydın, 2017; McDonald, 2010; Cengiz, \& Kabapınar, 2017; Yerrick, 2000). For instance, the study of Khishfe (2012), conducted with 11th graders, suggested that exposing students to relevant socio-scientific issues might increase their views on NOS and their argumentation skills. The present study findings were consistent with previous studies reported in the literature section.

\section{Conclusion and Recommendations}

In recent years, argument-based instruction has been frequently used in science education. Using argument-based activities in science education allows students to produce scientific knowledge. Thus, the contribution of argument-based activities to students has been discussed. In this study, the effects of argument-based laboratory method on pre-service teachers' scientific process skills and their perceptions on the nature of science were examined. The findings revealed that the argument-based laboratory method improved the pre-service classroom teachers' scientific process skills and positively affected their perceptions on the nature of science.

In the renewed classroom teacher undergraduate curriculum, laboratory applications were reduced from two semesters to one semester (Council of Higher Education [CHE], 2018). Reducing laboratory applications to a single semester limits the science education. The laboratory course should be instructed more intensively. Thus, argumentation, as a contemplative activity in laboratory applications, would increase the effectiveness of this course.

The literature review showed that studies on science education were mostly conducted with the study groups that consist of elementary school students and pre-service science, chemistry, and biology teachers. Considering that classroom teachers instruct the third and fourth grade students when the science course was introduced for them for the first time, future studies on science courses should focus on pre-service classroom teachers.

\section{References}

Acar, Ö., Tola, Z., Karaçam, S., \&Bilgin, A. (2016). Argümantasyon destekli fen öğretiminin 6. sınıf öğrencilerinin kavramsal anlamalarına, bilimsel düşünme becerilerine ve bilimin doğası anlayışlarına olan etkisi [Effect of argumentation supported science instruction on 6th graders' understanding of conceptual knowledge, scientific reasoning skills and nature of science]. Abant İzzet Baysal Üniversitesi Eğitim Fakültesi Dergisi, 16(3), 730-749.

Akkus, R., Günel, M., \& Hand, B. (2007). Comparing an inquiry based approach known as the science writing heuristic to traditional science teaching practices: Are there differences? International Journal of Science Education, 29(14), 1745-1765. https://doi.org/10.1080/09500690601075629

Alkış Küçükaydın, M., \& Uluçınar Sağır, Ş. (2016). Examination of the argumentation processes of classroom teachers participating in on-the-job training activities. Participatory Educational Research (PER), 3(2), 34-50. https://doi.org/10.17275/per.16.08.3.2

American Association for the Advancement of Science. (1993). Benchmarks for scientific literacy. New York: $\begin{array}{llll}\text { Oxford University } & \text { Press. } & \text { Retrieved }\end{array}$ 
http://www.project2061.org/publications/bs1/online/index.php?chapter=1\#A2

Aslan, S. (2010). Ortaöğretim 10. sinlf öğrencilerinin üst bilimsel süreç ve eleştirel düşünme becerilerinin gelişstirilmesine bilimsel tartışma odaklı öğretim yaklaşımının etkisi [Unpublished doctoral dissertation]. Gazi Üniversitesi, Ankara.

Aydoğdu, B., \& Buldur, S. (2013). Sınıf öğretmeni adaylarinin bilimsel süreç becerilerinin bazi değişkenler açisindan incelenmesi [An Investigation of pre-service classroom teachers' science process skills in terms of some variables]. Kuramsal Eğitimbilim Dergisi, 6(4), 520-534.http://dx.doi.org/10.5578/keg.6713

Bell, P., \& Linn, M. (2000). Scientific arguments as learning artifacts: Designing for learning from the web with KIE. International Journal of Science Education, 22(8), 797-817. https://doi.org/10.1080/095006900412284

Burns, J. C., Okey, J. R., \& Wise, K. C. (1985). Development of an integrated process skill test: TIPS II. Journal of Research in Science Teaching, 22(2), 169-177. https://doi.org/10.1002/tea.3660220208

Büyüköztürk, Ş. (2001). Deneysel desenler, öntest-sontest, kontrol grubu desen ve veri analiz kitabl. Pegem A.

Büyüköztürk, Ş., Çokluk, Ö., \& Köklü, N. (2018). Sosyal bilimler için istatistik. Pegem A.

Çalışkan, İ. Ö., \& Kaptan, F. (2012). Fen öğretiminde performans değerlendirmenin bilimsel süreç becerileri, tutum ve kalıcılık açısından yansımaları (Reflections of performance assessment on science process skills attitude and retention in science education]. Hacettepe Üniversitesi Eğitim Fakültesi Dergisi, 43, 117-129.

Cengiz, C., \& Kabapınar, F. (2017). Dolaylı Fen Öğretiminde Hizmet Öncesi Argümantasyon Eğitiminin Öğretmen Adaylarının Bilimin Doğasını Kavramalarına Etkisi [Effect of Implicit Argumentation Education on PSTs' Understandings about NOS]. Türkiye Kimya Derneği Dergisi, Kısım C: Kimya Eğitimi, 2(1), 19-62.

Çetin, P. S., Erduran, S., \& Kaya, E. (2010). Understanding the nature of chemistry and argumentation: the case of pre-service chemistry teachers. Ahi Evran Ünv. Kırşehir Eğitim Fakültesi Dergisi, 11(4), 41-59.

Cohen, J. (1988). Statistical power analysis for the behavioral sciences. Lawrence Erlbaum Associates.

Cohen, J. (1992). A power primer. Psychological Bulletin, 112(1), 155-159. https://doi.org/10.1037/0033-2909.112.1.155

Cook, L. K., \& Buck, G. A. (2013). Pre-service teachers' understanding of the nature of science through socioscientific inquiry. Electronic Journal of Science Education, 17(1), 1-23.

Council of Hihger Education (CHE). (2018). Öğretmen yetiştirme lisans programları. Ankara.

Demircioğlu T., \& Uçar S. (2015). Investigating the effect of argument-driven inquiry in laboratory instruction. Kuram ve Uygulamada Egitim Bilimleri, 15, 267-283.

Doğan, N., Çakıroğlu, J., Bilican, K., \& Çavuş, S. (2009). Bilimin doğası ve öğretimi. Pegem A.

Driver, R., Leach, J., Millar, R., \& Scott, P. (1996). Young people's images of science. Open University Press.

Driver, R., Newton, P., \& Osborne, J. (2000). Establishing the norms of scientific argumentation in classrooms. Science Education, 287-312. https://doi.org/10.1002/(SICI)1098-237X(200005)84:3<287::AID-SCE1>3.0.CO;2-A

Field, A. (2009). Discovering statistics using Spss. Oriental Press.

Geban, O., Askar, P., \& Ozkan, I. (1992). Effects of computer simulations and prob-lem-solving approaches on high school students. Journal of Educational Research, 86, 5-10. https://doi.org/10.1080/00220671.1992.9941821

Guler, B., \& Sahin, M. (2019). Using inquiry-based experiments to improve pre-service science teachers' science process skills. International Journal of Progressive Education, 15(5), 1-18. https://doi.org/10.29329/ijpe.2019.212.1

Gültepe, N. (2011). Bilimsel tartışma odakl öğretimin lise öğrencilerinin bilimsel süreç ve eleştirel düşünme becerilerinin geliştirilmesine etkisi [Unpublished doctoral dissertation]. Gazi Üniversitesi, Ankara.

Gultepe, N., \& Kilic, Z. (2015). Effect of scientific argumentation on the development of scientific process skills in the context of teaching chemistry. International Journal of Environmental \& Science Education, 10, 111-132.

Gümrah, A. (2013). Bilimsel tartişma yönteminin ortaöğretim öğrencilerinin kimyasal değişimler konusunu anlamalari, bilimin doğasi hakkindaki görüşleri, bilimsel süreç, iletişim ve argüman becerileri üzerine etkisi [Unpublished doctoral dissertation]. Marmara Universitesi, İstanbul. 
Harlen, W. (1999). Purposes and procedures for assessing science process skills. Assessment in Education: Principles, Policy \& Practice, 6(1), 129-144, https://doi.org/10.1080/09695949993044

Harlen, W. (2000). Teaching, Learning and Assessing Science 5-12 (3rd ed.). Paul Chapman Publishing Co.

Harlen, W., Macro, C., Reed, K., \& Schilling, M. (2003). Making progress in primary science: A study book for teachers and student teachers. Routledge Falmer. https://doi.org/10.4324/9780203426388

Jiménez-Aleixandre, P. M., \& Erduran, S. (2007). Quality argumentation and epistemic criteria. In S. Erduran \& M.P. Jime'nez- Aleixandre (Eds.), Argumentation in science education: Perspectives from classroom-based research (pp. 3-27). Springer. https://doi.org/10.1007/978-1-4020-6670-2_1

Karahan, Z. (2006). Fen ve teknoloji dersinde bilimsel süreç becerilerine dayalı ögrenme yaklaşımının öğrenme ürünlerine etkisi [Unpublished master thesis]. Zonguldak Karaelmas Üniversitesi Sosyal Bilimler Enstitüsü.

Kelly, G. J., Chen, C., \& Crawford, T. (1998). Methodological considerations for studying science-in-the-making in educational settings. Research in Science Education, 28(1), 23-49. https://doi.org/10.1007/BF02461640

Khishfe, R. (2012). Relationship between nature of science understandings and argumentation skills: A role for counterargument and contextual factors. Journal of Research in Science Teaching, 49(4), 489-514. https://doi.org/10.1002/tea.21012

Köseoğlu, F., Tümay, H., \& Budak, E. (2008). Bilimin doğası hakkında paradigma değişimleri ve öğretimi ile ilgili yeni anlayışlar [Paradigm changes about nature of science and new teaching aproaches]. Gazi Eğitim Fakültesi Dergisi, 28(2), 221-237.

Kuhn, D. (2005). Education for thinking. Harvard University Press.

Kutluca, A. Y., \& Aydın, A. (2017). Changes in Pre-service Science Teachers' Understandings After Being Involved in Explicit Nature of Science and Socioscientific Argumentation Processes. Sci \& Educ, 26, 637-668. https://doi.org/10.1007/s11191-017-9919-x

Latour, B. (1987). Science in action: How to follow scientists and engineers through society. Harvard University Press.

Lederman, N. G. (2007). Handbook of research in science education. Lawrence Erlbaum Publishers.

Lederman, N. G. (2007). Nature of Science: Past, Present, and Future. In S.K. Abell, \& N.G. Lederman (Eds.), Handbook of Research on Science Education (pp. 831-880).

Lemke, J. L. (1990). Talking science: Language, learning and values. NJ: Ablex.

McDonald, C. V. (2010). The influence of explicit nature of science and argumentation instruction on preservice primary teachers' views of nature of science. Journal of Research in Science Teaching, 47(9), 1137-1164. https://doi.org/10.1002/tea.20377

McDonald, C. V., \& McRobbie, C. J. (2012). Utilising argumentation to teach nature of science. In B.J. Fraser, K. Tobin, \& C. McRobbie (Eds.), Second international handbook of science education (s. 969-986), Springer. https://doi.org/10.1007/978-1-4020-9041-7_64

MEB. (2005). Illköğretim fen ve teknoloji dersi (4 ve 5. sinıflar) öğretim programı. Ankara.

Milli Eğitim Bakanlığı (2013). Fen bilimleri dersi öğretim programı. Ankara.

Milli Eğitim Bakanlığı (2018). Fen bilimleri dersi öğretim programı. Ankara.

National Research Council. (1996). National science education standards. National Academic Press.

Ogunniyi, M. B. (2006). Using an argumentation-instrumental reasoning discourse to facilitate teachers' understanding of the nature of science. International Conference of the National Association of Research in Science Teaching (NARST), San Francisco.

Özgelen, S. (2013). Bilimin doğası ölçeğinin geliştirilmesi [Development of nature of science scale]. Kastamonu Ë̆itim Dergisi, 21(2), 711-736.

Özmen, H., \& Yiğit, N. (2005). Teoriden uygulamaya fen bilgisi öğretiminde laboratuar kullanimi. Anı Yayınc1lık.

Padilla, M. J. (1990). The science process skills. Research matters-To the science teacher. National Association for Research in Science Teaching (NARST). Retrieved from http://www.narst.org/publications/research/skill.cfm

Poock, J. R. (2005). Investigating the effectiveness of implementing the science writing heuristic on student 
performance in general chemistry [Unpublished doctoral dissertation]. Iowa State University.

Rosenthal, R. (1991). Meta-analytic procedures for social research. Applied Social Research Methods Series 6. Sage Publications. https://doi.org/10.4135/9781412984997

Şahin Pekmez, E., Aktamiş, H., \& Can, B. (2010). Fen laboratuari dersinin öğretmen adaylarinin bilimsel süreç becerileri ve bilimsel yaraticiliklarina etkisi [The Effectiveness of Science Laboratory Course Regarding the Scientific Process Skills and Scientific Creativity of Prospective Teachers]. İnönü Üniversitesi Eğitim Fakültesi Dergisi, 11(1), 93-112. https://dergipark.org.tr/tr/pub/inuefd/issue/8703/108677.

Sampson, V. D., \& Clark, D. B. (2006). Assessment of argument in science education: A critical review of the literature. 7th International Conference on Learning sciences Bloomington, Indiana.

Sekerci, A. R., \& Canpolat, N. (2014). Effect of argumentation on prospective science teachers' scientific process skills and their understanding of nature of scientific knowledge in chemistry laboratory. Üniversitepark Bülten, 3(1-2), 7-18. https://doi.org/10.12973/unibulletin.312.1

Şimşekli, Y., \& Çalış, S. (2008). Sinif öğretmenliği öğrencilerinde bilimsel süreç becerilerinin gelişimine fen bilgisi laboratuvari dersinin etkisi [The effect of science laboratory lesson upon the improvement of science process skils of elementary education students]. Uludağ Üniversitesi, Eğitim Fakültesi Dergisi, XXI(1), 183-192.

Taşar, M. F. (2003). Teaching history and the nature of science in science teacher education programs. Pamukkale Üniversitesi Ĕ̈itim Fakültesi Dergisi, 1(13), 30-42.

Tümay, H., \& Köseoğlu, F. (2010). Bilimde Argümantasyona Odaklanan Etkinliklerle Kimya Öğretmen Adaylarının Bilimin Doğası Hakkındaki Anlayışlarını Geliştirme [Promoting pre-service chemistry teachers' understanding of nature of science with argumentation focused activities in science]. G̈̈, Gazi Eğitim Fakültesi Dergisi, 30(3), 859-876.

Ulu, C., \& Bayram, H. (2014). Fen öğretiminde laboratuvar uygulamalarında araştırma sorgulamaya dayalı bir yaklaşım: Bilim yazma aracı [Laboratory applıcatıons based inquiry approach in science teachıng: science writing heuristic]. International Journal of New Trends in Arts, Sports \& ScienceEducation, 3(4), 21-35.

Uluçınar-Sağır, Ş., \& Kılıç, Z. (2013). İlköğretim öğrencilerinin bilimin doğasını anlama düzeylerine bilimsel tartışma odaklı eğitimin etkisi [The effect of argumentatıon based teachıng on the understandıng levels of prımary school students about the nature of science]. Hacettepe Üniversitesi Eğitim Fakültesi Dergisi, 44, 308-318.

Walker, J. P., \& Sampson, V. (2013). Learning to argue and arguing to learn: Argument-driven inquiry as a way to help undergraduate chemistry students learn how to construct arguments and engage in argumentation during a laboratory course. Journal of Research in Science Teaching, 50(5), 561-596. https://doi.org/10.1002/tea.21082

Walker, J. P., Sampson, V., Grooms, J., Anderson, B., \& Zimmerman, C. O. (2012). Argument-driven inquiry in undergraduate chemistry labs: The impact on students' conceptual understanding argument skills, and attitudes toward science. Journal of College Science Teaching, 41(4), 74-81.

Walker, J. P., Sampson, V., \& Zimmerman, C. O. (2011). Argument-driven inquiry: An introduction to a new instructional model for use in undergraduate chemistry labs. Journal of Chemical Education, 88(8), 1048-1056. https://doi.org/10.1021/ed100622h

Yerrick, R. K. (2000). Lower track science students' argumentation and open inquiry instruction. Journal of Research in Science $\quad$ Teaching, 807-838. https://doi.org/10.1002/1098-2736(200010)37:8\%3C807::AID-TEA4\%3E3.0.CO;2-7

Yildırım, C. (2010). Bilim Felsefesi. Remzi Kitabevi.

\section{Note}

The present study was based on the master's thesis submitted by the first author and advised by the second author.

\section{Copyrights}

Copyright for this article is retained by the author(s), with first publication rights granted to the journal.

This is an open-access article distributed under the terms and conditions of the Creative Commons Attribution license (http://creativecommons.org/licenses/by/4.0/). 